\title{
Ethnomedicinal uses and therapeutic potential of some selected medicinal plants: A review
}

\author{
Dandu Chaithra, Baira Venkatesham, Mohd Nazeer, Mohammed Abdul Rasheed Naikodi^, Aslam Siddiqui, Javed Inam \\ Siddiqui and Ahmed Minhajuddin \\ Drug Standardization Research Unit, National Research Institute of Unani Medicine for Skin Disorders, A.G. Colony Road, Erragadda, \\ Hyderabad-500038, Telangana State, India
}

\begin{tabular}{l} 
Article Info \\
\hline Article history \\
Received 5 April 2021 \\
Revised 8 May 2021 \\
Accepted 9 May 2021 \\
Published Online 30 June 2021
\end{tabular}

\section{Keywords}

Ethnomedicinal uses

Therapeutic values

Medicinal plants

Phytoconstituents

\begin{abstract}
Diverse ethnobotanical knowledge is available on traditional medicinal plants since ancient time in India. Medicinal plants are being interestingly studied by researchers from centuries ago. Furthermore, studies are being done in the field of botany, pharmacognosy, chemistry, pharmacology and biotechnology of medicinal plants and herbal drugs. The importance and significance of ethnomedicine have been globally. The preliminary knowledge from the tribal claims, folklore claims, house hold or home remedies, has provided a direction of research to many researchers led to the development of several novel drug discovery and lead molecules from the medicinal plants. The knowledge from the traditional medicinal plants has explored to a great extent, resulting into various therapeutic potentials from several secondary plant metabolites. The bioactive molecules derived from different medicinal plants are earlier reported in literature to possess various biological and pharmacological properties. The present review on selected six medicinal plants is to document the various biological and pharmacological properties and their therapeutic potentials used to treat various human ailments. The bioactive phytoconstituents mainly responsible for the therapeutic activity of the plant based extracts mostly for skin diseases, cardiovascular diseases, bronchitis, diarrhoea, arthritis and other diseases.
\end{abstract}

\section{Introduction}

The ethnobotanical study of selected six medicinal plants is being reported for their biological and pharmacological properties. The selected and most important medicinal plants under discussion are: (i) Boswellia serrata Roxb, (ii) Drimia indica (Roxb.) J.P. Jessop, (iii) Pittosporum floribundum Wight \& Arn, (iv) Aeschynomene aspera L., (v) Sebastiana chamaelea Muell.-Arg., and (vi) Cycas beddomei Dyer. The selected six plant species are naturally grown and mainly distributed in the Eastern Ghats. According to the Botanical Survey of India, IUCN guidelines issued for the endangered plants under Schedule-VI of wild life protection act 1972, Government of India (Rao, 1974) to conserve and protect species. The two endangered plants Cycas beddomei and Boswellia serrata need to conserve and develop propagation methods due to their high medicinal values. The six plant photographs are shown in the Figure 1. The present review also describes about the nature of phytoconstituents and their structures present in above medicinal plants. The information about the collection of plant parts from the local tribal community and utilization of herbs for ethnomedicinal purpose was very important in order to preserve the traditional knowledge and to carry out their scientific validation

Corresponding author: Dr. Mohammed Abdul Rasheed Naikodi Scientist, Drug Standardization Research Unit, National Research Institute of Unani Medicine for Skin Disorders, A.G. Colony Road, Erragadda, Hyderabad-500038, Telangana State, India E-mail: rasheed.crium@gmail.com Tel.: +91-9959840785

Copyright () 2021 Ukaaz Publications. All rights reserved.

Email: ukaaz@yahoo.com; Website: www.ukaazpublications.com
(Sharma et al., 2004; Prusti and Behera, 2007; Savithramma et al., 2007; Panda and Mishra, 2011; Sree et al., 2019). Further, information presented in Table 1, viz., botanical name, vernacular or local name and major chemical constituents (Figure 2), part used, therapeutic properties and medicinal uses.

\subsection{Boswellia serrata Roxb.}

Synonym Boswellia glabra Roxb. belongs to the family Burseraceae, and reported as endemic to India and has been recorded on dry hills and slopes, on gravelly soils of Uttar Pradesh, Bihar, Punjab, Gujarat, Madhya Pradesh, Peninsular India between an altitude ranges $275-900 \mathrm{~m}$. It grows upto $12-15$ feet in height, medium sized but highly branching tree (Kokate et al., 1990).

\subsubsection{Ethnomedicinal uses and medicinal properties of B. serrata}

Bark and gum-resin used to treat asthma, dysentery, ulcer, haemorrhoid, skin diseases, convulsions, bronchitis, diarrhoea, syphilitic diseases, chronic laryngitis, jaundice, ringworm, diaphoretic, astringent, diuretic, arthritis, cardiovascular diseases and conjunctivitis. Leaf powder was mixed with coconut oil and prepared into paste and applied externally to relieve joint pain (Sharma et al., 2004). Oleo gum-resin yield of $B$. serrata contains higher amount of essential oil as 3.30-9.37\% (Ali et al., 2008). Essential oil of gumresin most commonly used oils in aroma therapy. The gum-resin of B. serrata possesses analgesic activity in albino wistar rats in addition to its sedative effect (Menon and Kar, 1970). 


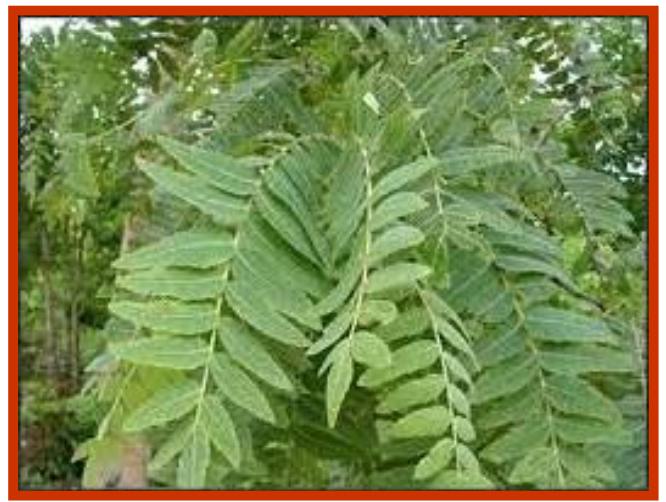

Boswellia serrata Roxb.

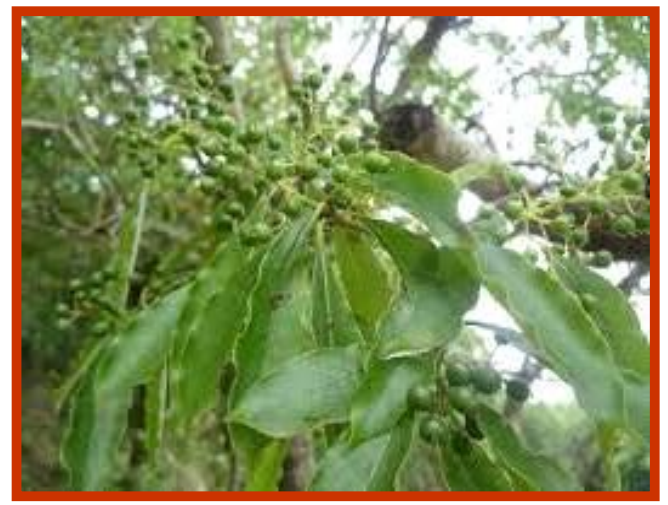

Pittosporum floribundum Wight \&Arn.

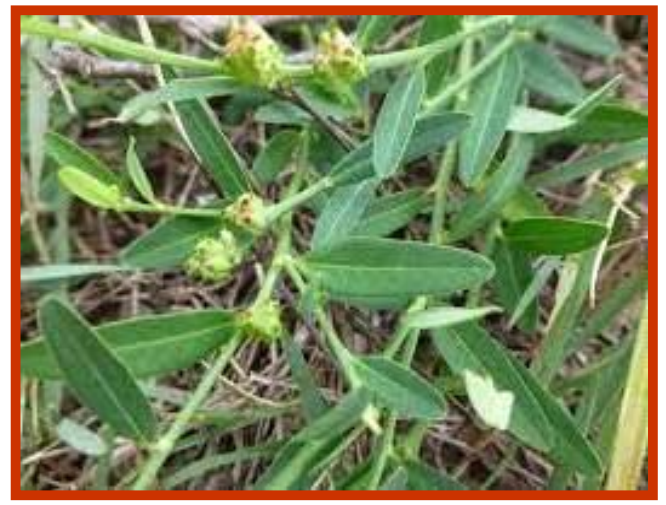

Sebastiana chamaelea Muell.-Arg.

Figure 1: Photographs of medicinal plants.

\subsubsection{Chemical constituents reported}

B. serrata contains not less than $1.0 \%$ of total acetyl-11-keto- $\beta$ boswellic acid and 11-keto- $\beta$-boswellic acid. The volatile oil composed of sesquiterpene alcohols, anisaldehyde, D- $\alpha$-thujone, $\alpha$-pinene, $\alpha$-phellandrene and phenolic compounds. Its gum mainly composed of araboinose with small amounts of xylose and galactose. Volatile oil contains D-limonene, terpenolene, $p$-cymene, $\alpha$-thujone, methyl chavicol (Kokate et al., 1990). B. serrata gum-resin extracts have been traditionally used in folk medicine to treat various chronic inflammatory diseases. It contains diterpenes, monoterpenes, triterpenes, tetracyclic triterpenic acids and four major pentacyclictriterpenic acids, i.e., $\beta$-boswellic acid, 11-keto- $\beta$ -

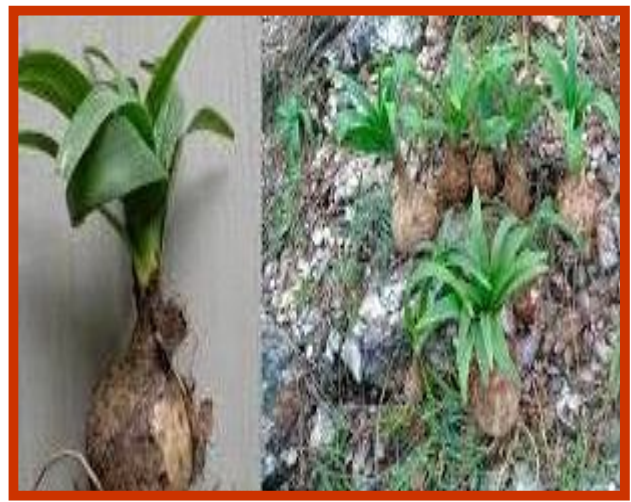

Drimia indica (Roxb.) J.P. Jessop

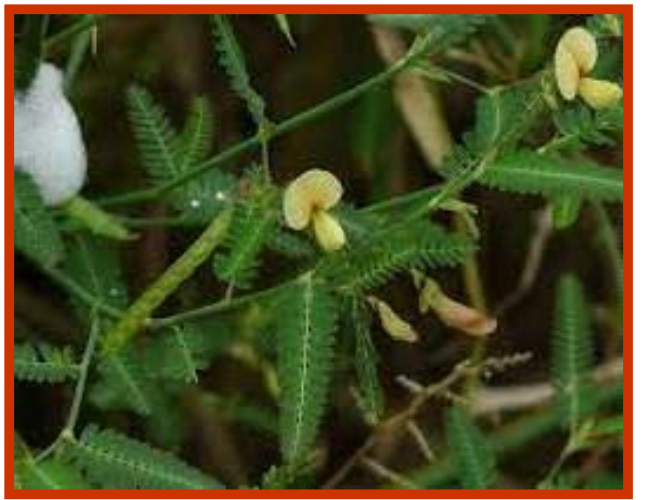

Aeschynomene aspera $\mathrm{L}$.

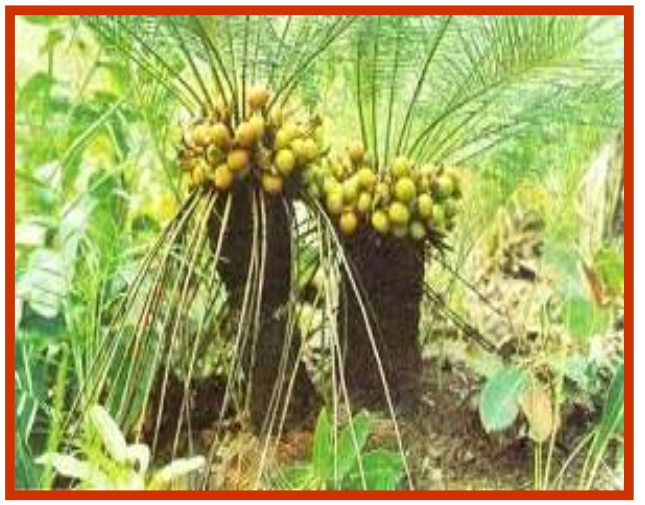

Cycas beddomei Dyer.

boswellic, acetyl-11-keto- $\beta$-boswellic and acetyl- $\beta$-boswellic acids responsible for inhibition of pro-inflammatory enzymes (Siddiqui, 2011).

\subsection{Drimia indica (Roxb.) J.P. Jessop}

Drimia indica (Roxb.) J.P. Jessop Syn. Urginea indica (Roxb) Kunth., belongs to Liliaceae family. The species globally distributed from Tropical Africa to Myanmar. Within India, it is found abundantly throughout the plains and in the dry hills of the lower Himalayas up to an altitude of $1500 \mathrm{~m}$. and cultivated in sandy soils near the sea-shore in the Deccan Peninsula and on an experimental basis in the lower Himalayas (Manning et al., 2004). 
Table1: Ethnomedicinal uses of some medicinal plants, chemical constituents and therapeutic activity

\begin{tabular}{|c|c|c|c|c|c|c|}
\hline S.No. & Plant name & $\begin{array}{l}\text { Vernacular } \\
\text { names }\end{array}$ & Part used & $\begin{array}{l}\text { Chemical } \\
\text { constituents }\end{array}$ & $\begin{array}{l}\text { Therapeutic } \\
\text { activity }\end{array}$ & $\begin{array}{l}\text { Ethnobotanical } \\
\text { use }\end{array}$ \\
\hline 1. & $\begin{array}{l}\text { Boswellia serrata } \\
\text { Roxb. }\end{array}$ & $\begin{array}{l}\text { Indian frankincense, } \\
\text { salai guggul }\end{array}$ & $\begin{array}{l}\text { Bark/leaf/ } \\
\text { oleo gum } \\
\text { resin }\end{array}$ & $\begin{array}{l}11 \text {-keto- } \beta \text {-boswellic, } \\
\text { acetyl-11-keto- } \beta \text { - } \\
\text { boswellic and acetyl- } \\
\beta \text {-boswellic acids, } \\
\text { D- } \alpha \text {-thujone, } \alpha \text {-pinene, } \\
p \text {-cymene, D-limonene, } \\
\text { terpenolene, } \alpha \text {-thujone } \\
\text { and methyl chavicol. }\end{array}$ & $\begin{array}{l}\text { Antiarthritic, } \\
\text { anticarcinogenicity } \\
\text { andanalgesic, } \\
\text { astringent, } \\
\text { diuretic activities. }\end{array}$ & $\begin{array}{l}\text { Asthma, dysentery, } \\
\text { ulcer, haemorrhoid, } \\
\text { convulsions, bronchitis, } \\
\text { diarrhoea, chronic } \\
\text { laryngitis, jaundice } \\
\text { and arthritis. }\end{array}$ \\
\hline 2. & $\begin{array}{l}\text { Drimia indica } \\
\text { (Roxb.) J.P. } \\
\text { Jessop }\end{array}$ & $\begin{array}{l}\text { Indian squill, true } \\
\text { squill, or sea onion, } \\
\text { adavivulli }\end{array}$ & Bulb & $\begin{array}{l}\text { Coumarin salicylic acid; } \\
\text { kaempferol, quercitin, } \\
\text { luteolin and apigenin } \\
\text { tartronic acid and } \\
\text { paraldehyde. }\end{array}$ & $\begin{array}{l}\text { Antihypertension } \\
\text { Antiosteoporosis, } \\
\text { Antiseptic, } \\
\text { Anti-arrhythmia, } \\
\text { Anti-inflammatory, } \\
\text { antitumour and } \\
\text { analgesic activities. }\end{array}$ & $\begin{array}{l}\text { Joint pains, ulcerss- } \\
\text { corpion sting, } \\
\text { psoriasis, } \\
\text { asthma and various } \\
\text { dermatological } \\
\text { diseases. }\end{array}$ \\
\hline 3. & $\begin{array}{l}\text { Pittosporum flori- } \\
\text { bundum Wight } \\
\text { \& Arn }\end{array}$ & Chettu-kasidra & $\begin{array}{l}\text { Stem bark/ } \\
\text { leaf }\end{array}$ & $\begin{array}{l}\text { Linalool, methyl } \\
\text { salicylate, dipentene, } \\
\text { alpha-pinene, cineol, } \\
\text { eugenol, n-dodecanoic } \\
\text { acid, n-tetradecanal } \\
\text { and } \beta \text {-acoradiene butyl } \\
\text { methyl ketone. }\end{array}$ & $\begin{array}{l}\text { Hepatoprotective, } \\
\text { antifungal, } \\
\text { anti-inflammatory, } \\
\text { antibacterial, } \\
\text { antioxidant, neuro- } \\
\text { pharmacological } \\
\text { and behaviour } \\
\text { activities. }\end{array}$ & $\begin{array}{l}\text { Diabetes, rheumatism, } \\
\text { chest pain, leprosy, } \\
\text { sprain, antidote, } \\
\text { eczema, snake } \\
\text { biteleprosy, asthma } \\
\text { and chronic bronchitis. }\end{array}$ \\
\hline 4. & $\begin{array}{l}\text { Aeschynomene } \\
\text { aspera } \mathrm{L} .\end{array}$ & $\begin{array}{l}\text { Sola pith plant, } \\
\text { pith plant, jiluga } \\
\text { bendu }\end{array}$ & $\begin{array}{l}\text { Aerial parts/ } \\
\text { pith }\end{array}$ & $\begin{array}{l}\text { Quercetin, } \\
\text { apigeninflavones } \\
\text { and myricetin. }\end{array}$ & $\begin{array}{l}\text { Analgesic, } \\
\text { antioxidant } \\
\text { antidiarrheal, } \\
\text { anti-inflammatory, } \\
\text { antifungal and } \\
\text { anthelmintic } \\
\text { activities. }\end{array}$ & $\begin{array}{l}\text { Joint pains, } \\
\text { swellings, jaundice, } \\
\text { fever, cold, cough, } \\
\text { and urinary troubles. }\end{array}$ \\
\hline 5 . & $\begin{array}{l}\text { Sebastiana } \\
\text { chamaelea Muell. } \\
\text {-Arg. }\end{array}$ & $\begin{array}{l}\text { Kodiyaavanakku, } \\
\text { karkidaka kanji }\end{array}$ & Whole plant & $\begin{array}{l}\text { Myricetin, quercetin, } \\
\text { kaempferol, luteolin, } \\
\text { apigenin, triterpenoids. }\end{array}$ & $\begin{array}{l}\text { Anti-inflammatory, } \\
\text { antipyretic, } \\
\text { antimicrobial, } \\
\text { antioxidant activities. }\end{array}$ & $\begin{array}{l}\text { Headache, } \\
\text { vertigodiarrhoea } \\
\text { and syphilis. }\end{array}$ \\
\hline 6. & $\begin{array}{l}\text { Cycas beddomei } \\
\text { Dyer. }\end{array}$ & Peritha & $\begin{array}{l}\text { Leaf/pith/ } \\
\text { Bark/male } \\
\text { and female } \\
\text { cones }\end{array}$ & $\begin{array}{l}1,3- \\
\text { Propanediol, } \\
\text { Methyl tetradecanoate, } \\
\text { hexadecanoic acid, } \\
\text { methyl ester and } \\
\text { Methyl cis-7- } \\
\text { octadecenoate. }\end{array}$ & $\begin{array}{l}\text { Antimicrobial, } \\
\text { anti-inflammatory, } \\
\text { antiarthritic, } \\
\text { antidiabetic } \\
\text { activities. }\end{array}$ & $\begin{array}{l}\text { Ulcers, hyperacidity, } \\
\text { boils, skin diseases } \\
\text { arthritis anddiabetes. }\end{array}$ \\
\hline
\end{tabular}

\subsubsection{Ethnomedicinal uses and medicinal properties of D. indica}

Bulb powder paste can be locally applied to remove warts, externally for joint pains (Nadkarni, 1976; Prusti and Behera, 2007). The bulb paste along with oil of Mahua (Madhuca longifolia) can be used on affected part of the body and to cure ulcers (Dinesh and Ashok, 2003). The bulb paste of $D$. indica used against scorpion sting (Kala, 2009) and also for Pyrexia and antinematod (Choudary et al., 2008). Mostly used traditionally by many tribes and aborigines against psoriasis, asthma and dermatological diseases (Vahdettin and Vahit, 2010). It acts as potent rodenticide and has been used in the treatment of lymphedema (Farinola and Piller, 2005), also reported to have antihypertension, antiosteoporosis, antiseptic antiarrhythmia, anti-inflammatory, antitumour and analgesic properties (Liu, 2010).

\subsubsection{Chemical constituents of whole plant of $D$. indica}

Chemical constituents of whole plant of $D$. indica reported to possess phenolic compounds like coumarin and salicylic acid; flavonoids like kaempferol, quercetin, luteolin and apigenin (Dinesh and Ashok, 2003). D. indica bulb was found to have tartronic acid and paraldehyde as potential bioactive compounds (Armstrong and Battiu, 2001). D. indica contains salicylic acid which helps in the control of nausea and diarrhoeal activities and coumarin used in the pharmaceutical industries as a precursor molecule in the synthesis of anticoagulant pharmaceuticals (Johnson et al., 2009). 


(n)




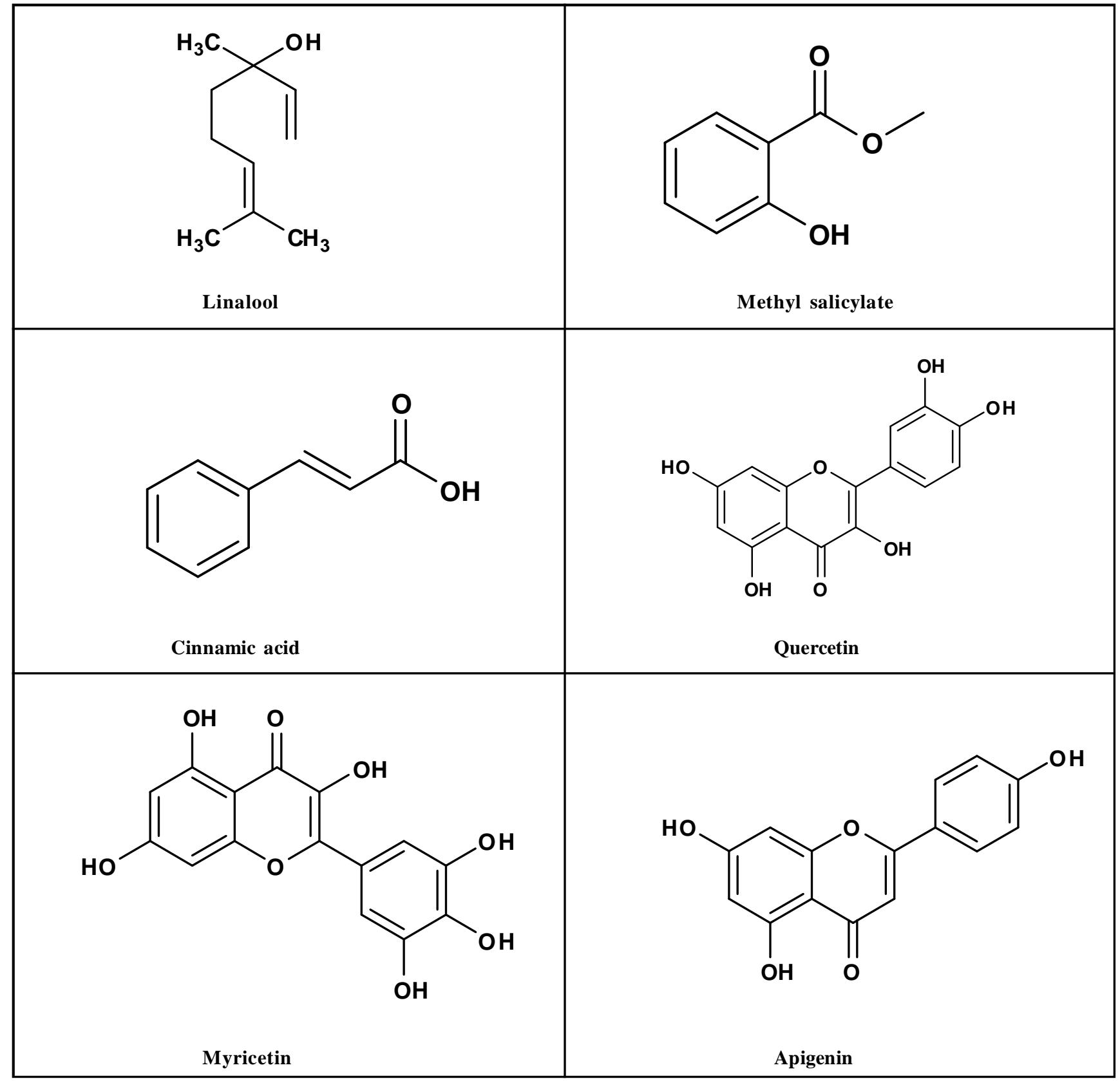

Figure 2: Chemical structures of main phytoconstituents of above selected medicinal plants.

\subsection{Pittosporum floribundum Wight \&Arn Syn.}

P. napaulense Rehder and Wilson of Bixaceae family. A small evergreen tree, observed in Himalayas from Punjab, east wards to the hills of Assam and Peninsular India, ascending up to an altitude of $2400 \mathrm{~m}$ (Kirtikar and Basu, 1975; Pullaiah, 2006).

\subsubsection{Ethnomedicinal uses}

P. floribundum leaves and stem bark were used to treat diabetes, arthritis, chest pain, leprosy, rheumatism, sprain, antidote, eczema and for snake bite. Bark methanolic extract having anti-inflammatory, hepatoprotective, antibacterial, antioxidant, antifungal, behaviour and neuropharmacological activities (Kishangiri et al., 2020). Bark (aqueous), leaf (methanol) and fruit (alcohol) extracts has effective antifungal and antibacterial activity adjacent to tested bacteria to that of control group (Nagamalleswari et al., 2013). Bark powder mainly used for leprosy, leprous affections, chronic rheumatism, cutaneous disease, asthma, chronic bronchitis and secondary syphilis (Savithramma et al., 2007). Bark decoctions are generally used to treat chest infection, skin disease, stomach complaints, abdominal pain and fever (Burkil, 2004).

\subsubsection{Chemical constituents}

Different parts of alcoholic extracts were subjected to phytochemical screening for the presence of phytoconstituents such as flavonoids, alkaloids, lignins, phenols, steroids, anthroquinones, 
saponins, tannins, fixed oils and glycosides (Kishangiri et al., 2020). Plant yields an essential oil (0.26\%) with linalool, methyl salicylate, dipentene, alpha-pinene, cineol, anisaldehyde, eugenol, benzoic and salicylic acids as major constituents. Hydrodistillation of stem bark of $P$. floribundum gave oil of $0.9 \%$ yield, based on the dry weight of the plant. The main constituents are n-tetradecanal with $60.1 \%$, $\beta$-acoradiene with $0.3 \%$ and butyl methyl ketone with $4.3 \%$ (Sreelekha, 2012).

\subsection{Aeschynomene aspera $\mathrm{L}$.}

A. aspera belongs to family Fabaceae, a tall erect subshrub in swampy areas; native to Bangladesh, Bhutan, India, Indonesia, Malaysia, Myanmar, Thailand and Vietnam.

\subsubsection{Ethnomedicinal uses}

Leaves are used to cure joint pains and swellings (Padal et al., 2010). Aerial parts juice used to cure fever, cold, cough, increase the consistency of semen and urinary troubles (Panda and Mishra, 2011). Bioactivity study such as in vitro antioxidant activity by free radical diphenylpicrylhydrazyl (DPPH) scavenging assay, total flavonoid and phenolic contents, antidiarrheal and analgesic activities were evaluated by acetic acid induced writhing inhibition in albino rats and castor oil induced diarrheal in parasites (Imtiaz et al., 2020).

\subsubsection{Chemical constituents}

Phenolic compounds like protocatechuic acid acts as antioxidant and antimutagenic (Tanka et al., 1995). Protocatechuic acid acts against influenza virus (Lu et al., 2002). Chlorogenic acid acts as antifungal, antibacterial and anti-inflammatory agent (Sotillo et al., 1998). Caffeic acid prevents type 2 diabetes mellites (Paynter et $a l ., 2006)$. Caffeic acid acts as anti-inflammatory and trans-pcoumaric acid as antibacterial agent (Pereira et al., 2007). Cinnamic acid acts against herpes and influenza virus (Ivanka et al., 2008). Flavonoid compounds exhibits antiallergic, antiviral, antiinflammatory and vasodilatory activities in human beings. These compounds are used in the treatment of dermatitis, hemorrhage and albuminuric diseases. Quercetin possesses anti-inflammatory and antioxidant properties (Laura et al., 2008). Myricetin plays a significant role in inhibiting the tumor growth and enhancing the diuretic and diaphoretic activities. Myricetin lowers the rates of prostate cancer (Knekt et al., 2002). Flavones reduce the risk of pancreatic cancer (Nothlings et al., 2007), jaundice and hepatitis (Abbasi et al., 2008). Apigenin showed its anti-inflammatory activity (Pieroni et al., 2000).

\subsection{Sebastiana chamaelea Muell.-Arg.}

S. chamaelea Muell. Arg. A perennial herb of family Euphorbiaceae, mainly distributed from Maharashtra, Karnataka, Mysore, Kerala, Tamilnadu (Esser, 1999).

\subsubsection{Ethnomedicinal uses}

Leaf decoction of the plant in ghee was given as tonic and applied to the head in vertigo patients. The whole plant juice was astringent and used as a remedy for diarrhoea and syphilis. Whole plant accounted for $77.5 \%$ of human necessary amino acids of which argenine stands highest with $60 \%$ of free amino acids, may promote the role for its medicament activity (Sree et al., 2010). Phytochemical constituents like saponins, steroids, flavonoids, tannins and phenols are known to have anti-inflammatory and antipyretic activities (Polukonova et al., 2015). Antibacterial activities of leaf and callus extracts are tested against bacterial cell cultures by agar well diffusion method. Ethyl acetate and methanol extracts of leaf and leaf derived callus showed effective inhibitory effect in bacterial strains (Ganesan et al., 2013). Based on ethnobotanical data obtained from Nigerian and Senegalense traditional healers $S$. chamaelea traditionally used to treat malaria (Sree et al., 2019).

\subsubsection{Chemical constituents}

Phenolic acids such as cinnamic acid, coumarin, p-hydroxy benzoic acid salicylic acid, caffeic acid, melilotic acid,scopoletin, and aesculetin flavonoids like myricetin, quercetin, kaempferol, luteolin, apigenin, triterpinoids like betuline and glucoside of betulinic acid are found in S. chamaelea (Sree et al., 2010). Phenolic acids like caffeic acid has anti-inflammatory activity (Fernandez et al., 1998), while cinnamic acid has anthelmintic, antifungal properties and natural protection against infections caused by pathogenic microorganisms (Champbel et al., 1999).

\subsection{Cycas beddomei Dyer.}

Cycas beddomei Dyer. family Cycadaceae, an endemic medicinal plant known as "Peritha" by the local people of the Seshachalam hill ranges of the Eastern Ghats; confined to a small area of Andhra Pradesh state in the Tirumala Hills in scrubland and brush covered hills. It is identified as critically endangered as per IUCN criteria (Alekhya et al., 2012).

\subsubsection{Ethnomedicinal uses}

Male cone part used in ayurvedic medicine to cure for rheumatoid arthritis and muscle pains (Latheef et al., 2008; Rao, 2010). Pith can be used in diet for debility (Sudhakar et al., 2009). Traditional data collected from the Yandi tribe and local herbalists of Talakona area showed that Cycas beddomei leaves used to treat acidity and ulcers. Bark powder used to cure boils and skin diseases. Male cones used to cure arthritis and diabetes. Male and female cone used as an ideal food supplement and rejuvenator. Therapeutic activities of the species are antioxidant, antiulcer, aphrodisiac, debility, arthritis and diabetic conditions (Alekhya et al., 2012). Phenolic quinines act as anti-inflammatory and antiseptic. Tannins acts as antiseptic in the treatment of hemorrhages. It is also used in uterine diseases, diarrhoea and hypoglycemia (Kokate et al., 2007).

\subsubsection{Chemical constituents}

In Cycas beddomei plant, major phytochemical constituents have been identified by GC-MS such as 1,3-propanediol, mome inositol, $\beta$-sitosterol, tertradecanamide, methyl tetradecanoate, hexadecanoic acid, methyl cis-7-octadecenoate, methyl ester, etc. (Ravi et al., 2012).

\section{Conclusion}

The traditional medicinal plants are popularly known for their safety and prolong use for medicinal purpose. The above discussed medicinal plants possess important ethnomedicinal uses and therapeutic potentials. Previously some practical works on these endangered medicinal plants are carried out. The discussed medicinal plants revealed that they possess different medicinal properties 
and can be used to treat various disease conditions. Explore the medicinal plants further in the direction of pharmacological approaches and also for generation of scientific data for their efficacy and to develop new potent drugs to treat diseases like skin diseases, cardiovascular diseases, bronchitis, diarrhoea, arthritis and other inflammatory disorders. Plants are the major source for the drug discovery and isolation of bioactive marker compounds. There is a resilient need to conserve the endangered species like $C$. beddomei and $B$. serreta through in vivo and in vitro propagation for future studies.

\section{Acknowledgements}

The authors are thankful to the Director General, CCRUM, New Delhi, and also Director, NRIUMSD, Hyderabad for providing the necessary facilities.

\section{Conflict of interest}

The author declares that there are no conflicts of interest relevant to this article.

\section{References}

Abbasi, A.M.; Khan, M.A.; Ahmad, M.; Zafar, M.; Khan, H.; Muhammad, N. and Sultana, S. (2009). Medicinal plants used for the treatment of jaundice and hepatitis based as socio-economic documentation. Journal of African Biotechnology, 8(8):1643-1650.

Alekhya, C.; Yasodamma, N. and Chaithra, D. (2012). Physicochemical analysis and antimicrobial activity of Cycas beddomei Dyer. vegetative parts. Journal of Pharmacy Research, 5(5):2553-2558.

Ali, N.; Martina, W.; Nobert, A.; Teichert, A.; Jurgen, S.; Lindequist, U. and Ludger, W. (2008). Chemical composition and biological activities of essential oils from the oleo gum resins of three endemic soqotraen Boswellia Species. Records of Natural Products, 2(1):6-12.

Armstrong, D.L. and Battin, M.R. (2001). Pervasive seizures causes by hypoxie ischaemic encechalopathy treatment with intravenous paraldehyde. Journal of Child Neurology, 16(12):915-917.

Borrelli, F.; Capasso, F.; Capasso, R.; Ascione, V.; Aviello, G.; Longo, R. and Izzo, A.A. (2006). Effect of Boswellia serrata on intestinal motility in rodents: Inhibition of diarrhea without constipation. British Journal of Pharmacology, 148(4):553-560.

Burkil, H.M (2004). The useful plants of West Tropical Africa. Roya Botanic Gardens; Kew. Edition II, University Press of Virginia, Box 3608, University Station, Charlottesville, Vol. 1, pp:960.

Champbel, A.; Viegas, C.A. and Sacorreia I. (1999). Effect of cinnamic acid and the growth on plasma membrane H+ATPase activity of Saccharomyces cerevisae. International Journal of Food Microbiol, DOI:10.1016/S018-1605 (99)00100-2. Corpus ID. 84103467

Choudary, K.; Singh, M. and Pillai, U. (2008). Ethno botanical survey of Rajasthan: An update. American-Eurasian Journal of Botany, 1(2): 38-45.

Dinesh, K.T. and Ashok, Y. (2003). Ethnobotanical investigation of some medicinal plants availed by Gond tribe of Naoradehi wild life sanctuary, Madhya Pradesh. The Anthropologist, 5(3):201-202.

Esser, H.J. (1999). A partial revision of the Hippomaneae (Euphorbiaceae) in Malaysia. Blumea, 44(1):173-179.

Farinola, N. and Piller, N. (2005). Pharmacognostic: It's role in reestablishing coumarin as treatment for lymphedema. Lymphatic Research and Biology, 3(2):81-86.
Fernandez, M.A.; Saenz, M.T. and Garcia, M.D. (1998). Anti-inflammatory activity in rats and mice of phenolic acids isolated from Scrophularia frutescens. Journal of Pharmacy and Pharmacology, 50(10):11831186.

Ganesan, G.; Kamalanathan, D.; Ragavendran, C. and Natarajan, D. (2013). Screening of antibacterial and phytochemical analysis of leaf and leaf derived callus extracts of Sebastiania chamaelea (L.) Muell. Arg. Indo American Journal of Pharmaceutical Research, 3(10):1-7.

Imtiaz, H.; Hossain, A.; Islam, F.; Sultana, R. and Rahman, M.M. (2020). Bioactivities of Aeschynomene aspera (Fabaceae) leaf extract. Bangladesh Pharmaceutical Journal, 23(2):109-116.

Ivanka, S.; Kiril C.; Stoyan S.; Kalina, K.; Luchia, M. and Angel, S.G. (2008). Synthesis, antioxidative and antiviral activity of hydroxyl cinnamic Acid amides of thiazole containing amino acids. Journal of Amino Acids, 37(2):383-388.

Johnson, M.A.B.; Obi, C.L.; Kambizi, L. and Nkomo, M. (2009). A survey of indigenous herbal diarrheal remedies of O.R. Tambo district, Eastern Cape Province, South Africa. African Journal of Biotechnology, 9(8):1245-1254

Kala, C.P. (2009). Aboriginal uses and management of ethnobotanical species in deciduous forests of Chhattisgarh state in India. Journal of Ethnobiology and Ethnomedicine, 5(1):20.

Kirtikar, K.R. and Basu, B.D. (1975). Indian medicinal plants. Ed. B. Singh and SM Pal, Dehradun, India, 2:993-994.

Kishangiri, G.; Abhay, G.; Rabinarayan, A. and Shukla V.J. (2020). Ethnomedicinal uses, phytochemistry and pharmacological activities of Pittosporum floribundum Wight. \& Arn.: A review. European Journal of Medicinal Plants, 31(3):48-55.

Knekt, P.; Kumpulainen, J.; Jarvinen, R.; Rissanen, H.; Heliovaara, M.; Reunanen, A.; Hakulinen, T. and Aroma, A. (2002). Flavonoid intake and risk of chronic diseases. American Journal of Clinical Nutrition, 76(3): $560-568$.

Kokate, C.K. and Purohit, A.P. and Gokhale, S.B. (2007). Pharmacognosy, Nirali Prakashan, Pune, pp:330.

Kokate, C.K.; Purohit, A.P. and Gokhale, S.B. (1990). Pharmacognosy. $43^{\text {rd }}$ edition, 11(13):11-18.

Latheef, S.A.; Prasad, B.; Bavaji, M. and Subramanyam, G. (2008). A database on endemic plants at Tirumala Hills in India. Bioinformation, 2(6): 260-262.

Laura, K.S.; Jeff, L.S.; David, R.; Zhong, Q.W.; Ilya, R.; Alexander, P.; Martin, M.; William, T.C. and Thomas, W.G. (2008). Quercetin transiently increases energy expenditure but persistently decreases circulating markers of inflammation in C57BL/6J mice fed a high fat diet. Metabolism, 57(1):39-46

Liu, H.W. (2010). Extraction and isolation of compounds from herbal medicines in traditional herbal medicine research methods, Edn. by Willow JH Liu John Wiley and Sons, Inc. https://doi.org/10.1002/ 9780470921340.ch3.

Lu, F.J.; Tseng, S.N.; Li, M.L. and Shih, S.R. (2002). In vitro anti-influenza virus activity of synthetic human's analogues derived from protocatechuic acid. Journal of Archives of Virology, 147(2):273-284.

Manning, J.C.; Goldblatt, P. and Fay, M.F. (2004). A revised generic synopsis of Hyacintheaceae in sub-saharan Africa, based on molecular evidence, including new combinations and the new tribe pseudoprospereae. Edinburgh Journal of Botany, 60(3):533-568.

Menon, M.K. and Kar, A. (1970). Analgesic and psycho-pharmacological activity of gum resin of Boswellia serrata. Planta Medica, 19(4): 333-341. 
Nadkarni, A.K. (1976). Indian Materia Medica (with Ayurvedic, UnaniTibbi, Siddha, Allopathic, Homeopathic, Naturopathic and Home Remedies, Appendices and indexes) revised enlarged and reprinted 3rd edn, Bombay: Popular prakashan Pvt. Ltd, Vol. 1-2.

Nagamalleswari, K.; Yasodamma, N. and Binny, A.J. ((2013). Phytochemica screening, antibacterial and antifungal studies of Pittosporum floribundum Wight and Arn. leaf, bark, fruit and seed extracts International Journal of Pharma and Biosciences, 4 (2):464-474.

Nothlings, U.; Murphy, S.P.; Wilkens, L.R.; Henderson, B.E. and Kolnel, L.N. (2007). Flavonols and pancreatic cancer risk: The multiethnic cohort study. American Journal of Epidemiology, 166(8):924-931.

Padal, S.B.; Murthy, P.P.; Rao, D.S. and Venkaiah, M. (2010). Ethnomedicinal plants from Paderu Division of Visakapatnam District, A.P. India, Journal of Phytology, 2(8):70-91.

Panda, A. and Mishra, M.K. (2011). Ethnobotanical survey of some wetland plants of South Orissa and their conservation. Indian Journal of Traditional Knowledge, 10(2):296-303.

Paynter, N.P.; Yeh, H.C.; Voutilainen, S.; Schmidt, M.I.; Heiss, G.; Folson, A.R. Braneati. F.L. and Kao, W.H.L. (2006). Coffee and sweetened beverage consumption and the risk of type 2 diabetes mellitus. American Journal of Epidemology, 164(11):1075-1084.

Pereira, J.A.; Olieira, I.; Sousa, A.; Valentao, P.; Andrade, P.; Ferreira, I.; Ferreres, F.; Bento, A.; Seabra, R. and Estevingo, L. (2007). Walnut (Juglans regia) leaves, phenolic compounds, antibacterial activity and antioxidant potential of different cultivers. Food and Chemical Toxicology, 45(11):2287-2295.

Pieroni, A.; Pachaly, P.; Huaug, Y.; Vlietinek, A.J. and Poel, V.B. (2000). Studies on anti-complementary activity of extracts and isolated flavones from Ligustrum vulgare and Phillyrea latifolia leaves (Oleaceae). Journal of Ethno Pharmacology, 70(3):213-217.

Polukonova, N.V.; Navalokin, N.A.; Raikova, S.V.; Masliakova, G.N.; Bucharskaia, A.B.; Durnova, N.A. and Shub, G.M. (2015). Anti-inflammatory, antipyretic and antimicrobial activity of flavonoid-containing extract of Gratiola officinalis L. Eksp Klin Farmakol, 78(1):3438 .

Prusti, A.B. and Behera, K.K. (2007). Ethnobotanical exploitation of Malkangiri district of Orissa, India. Ethnobotanical Leaflets, 11: 122-140.

Pullaiah, T. (2006). Encyclopedia of world medicinal plants. Sal. Paratyphi, Regency Publication, 1st Edn. New Delhi, 2:1556-1557.

Rao, B.R.P. (2010). Cycas beddomei. IUCN red list of threatened species. Version 3, International Union for Conservation of Nature.

Rao, L.N. (1974). Cycas beddomei Dyer. Proceedings of the Indian Academy of Sciences, 79:59-67.
Ravi, K.N.; Satyanarayan, R.J.; Krishna, G.G. and Anand, S.K. (2012). GC-MS determination of bioactive constituents of Cycas beddomei cones. International Journal of Pharma and Biosciences, 3(3):344-350.

Savithramma, N.; Sulochana, C. and Rao, KN. (2007). Ethnobotanical survey of plants used to treat asthma in Andhra Pradesh, India. Journal of Ethnopharmacology, 113(1):54-61.

Sharma, S.; Thawani, V. and Hingorani, L. (2004). Pharmacokinetic study of 11-keto-beta-boswellic acid. Phytomedicine, 11(2-3):255-260

Siddiqui, M.Z. (2011). Boswellia serrata, A potential anti-inflammatory agent: An overview. Indian Journal of Pharmaceutical Sciences, 73 (3):255-261.

Sotillo, D.R.D.; Hadley, M. and Wolf-Hall, C. (1998). Potato peel extract a non-mutagenic antioxidant with potential antimicrobial activity. Journal of Food Science, 63(5):907.

Sree, K.S.S.; Yasodamma, N. and Paramageetham, C.H. (2010). Phytochemical screening and in vitro antibacterial activity of the methanolic leaf extract: Sebastiania chamaelea Muell. Arg. The Bioscan, 5(1): $173-175$

Sree, K.S.S; Latha, A.S.; Yasodamma, N. and D. Bharathi (2019). Phytochemical and pharmacological activities of an Euphorbian herb, Sebastiania chamaelea Muell. Arg. World Journal of Pharmacy and Pharmaceutical Sciences, 8(4):445-453.

Sreelekha, M. (2012). Studies on secondary plant metabolites and their biological properties. eLibrary ID: 23132617.

Sudhakar, R.C.; Reddy, K.N.; Murthy, E.N. and Raju, V.S. (2009). Traditional medicinal plants in Seshachalam Hills, Andhra Pradesh, India. Journal of Medicinal Plants Research, 3(5):408-412.

Tanaka, T.; Kojima, T.; Kalwamori, T. and Mori, H. (1995). Chemoprevention of digestive organs carcinogenesis by natural product protocatechuic acid. Cancer, 75(6): 1433-1439.

Tsukada, T.; Nakashima K. and Shirakewa, S. (1986). Archidonate 5lipoxygenase inhibitors show potent antiproliferative effects on human leukemia cells. Biochemical Biophysical Research Communication, 140(3):832-836

Vahdettin, B. and Vahit, K. (2010). Analgesic effects of scilliroside, proscillaridin-A and taxifolin from squill bulb (Urginea maritima) on pains digest. Journal of Nanomaterials and Biostructures, 5(2): 457-465.

Vernon, R. (1969). Lymphocyte to macrophages transformations in the peritoneal cavity proceeding the mobilization of peritoneal macrophages to inflamed areas. Nature, 222:1286-1288. 